\title{
Oral health of the prehistoric Rima Rau Cave burials, Atiu, Cook Islands
}

\author{
Angela L Clark ${ }^{1}$
}

\section{Christina Stantis ${ }^{2}$}

\section{Hallie R Buckley ${ }^{3}$}

\section{Nancy Tayles ${ }^{3}$}

${ }^{1}$ Sir John Walsh Research Institute, Faculty of Dentistry, University of Otago, New Zealand

${ }^{2}$ Department of Archaeology, Anthropology, and Forensic Science, University of Bournemouth, UK

${ }^{3}$ Department of Anatomy, University of Otago, New Zealand

angela.clark@otago.ac.nz

Angela Clark is a Lecturer in Forensic Biology. Her research focuses on investigating human variation and adaptability using dental and skeletal tissues as indicators of sex, disease, growth and development. Her main research interests are in dental and skeletal developmental plasticity, enamel defects, physiological stress and forensic anthropology/bioarchaeology.

Hallie Buckley is a Professor of Biological Anthropology, who explores patterns of prehistoric health and disease in the Asia-Pacific region as evidence of adaptation to the environment. Professor Buckley's research has focused on skeletal samples from the Island and Mainland Southeast Asia and the Pacific, including protohistoric New Zealand.

Chris Stantis is a Postdoctoral Researcher who is a bioarchaeologist specialising in stable isotope analysis of human remains to address questions of migration and diet.

Nancy Tayles is a retired Honorary Associate Professor of Biological Anthropology and her primary research focus is on the effects of changes in environment, subsistence, technology and social structure on the biology of prehistoric people, particularly in mainland Southeast Asia and the Pacific. 


\section{Oral Health of the prehistoric Rima Rau Cave Burials, Atiu, Cook Islands}

The human skeletal remains buried in the cave of Rima Rau on the small island of Atiu in the Southern Cook Islands have long been a subject of speculation as to their origins. Oral histories of a massacre, battle, famine and cannibal feast surround the sacred site. The local Atiuan community invited a group of bioarchaeologists from the University of Otago to help shed light on the people buried in the cave. We examined nearly 600 skeletal elements and 400 teeth, which represent at least 38 adults and 8 infants and children. This research is the assessment of their oral health, a first for a prehistoric Southern Cook Island population. Oral health was within the range of other tropical Pacific skeletal assemblages, for dental caries, antemortem tooth loss, and supragingival calculus, with low rates of periodontal disease and periapical cavities. Degeneration of the temporomandibular joint was high and this was associated with enamel chipping, possibly linked to diet. Enamel defect prevalence indicates sex-specific health differences, but the population was robust with a good proportion who survived to adulthood despite periods of early childhood stress. Through the consideration of a skeletal census and oral health indicators we begin to describe the burials in the cave.

Keywords: prehistory; oral pathology; Polynesia; diet; skeletal census; commingled remains; bioarchaeology

This work was supported by the University of Otago Research Grant under Grant [\#01130314].

\section{Introduction}

E u no te akau roaka

oki rai ki te akau roa

$$
\begin{aligned}
& \text { You can never forget } \\
& \text { where you came from } \\
& \text { Teiotu (2007, p.116) }
\end{aligned}
$$

Atiu is a $27 \mathrm{~km}^{2}$ raised coral limestone (makatea) island in the Southern Cook Islands, east Polynesia. Located at latitude $20^{\circ} \mathrm{S}$ and longitude $158^{\circ} 10^{\circ} \mathrm{W}$, it is the third largest island in the Cook Islands, with a circumference of $20 \mathrm{~km}$ (Figure 1). The island is roughly quadrilateral in shape, and divided into three distinct geographic regions: 1) the weathered volcanic interior, 2) the raised coral limestone rim, or makatea, and 3) the swampy lowland depression that separates the first and second region (Figure 1). The makatea surface is rough and uneven with sinkholes, caves, underground drainage, and craggy limestone pinnacles 
(Wood and Hay 1970).

Throughout the makatea islands of Polynesia, caves are commonly used as sites of human habitation, fortified refuge, storage and the interment of human remains (Table 1). The use of caves as burial sites in Polynesia is most extensively documented on the makatea island of Mangaia in the Southern Cook Islands (Antón and Steadman 2003). Oral histories from Mangaia report that the interment of the dead in a cave, either as primary or secondary burials, was commonplace to keep "them safe from interference by enemies" (Buck 1934, p. 191).

In 1969, Trotter and Duff (Trotter 1974) conducted an archaeological expedition organised by the Royal Society of New Zealand. In their survey, Trotter and Duff recorded six caves, three of which were burial caves (Trotter 1974). In 1987, with the aim of finding prehistoric birds remains, Steadman (1991) carried out a survey of 16 caves on Atiu, including three human burial caves. Except for the brief mention of 'Te Ana Rima Rau' in Mana et al. (1984), Steadman (1991) provides the first published account naming and describing the location of Rima Rau burial cave. In relation to the use of caves on Atiu, Gill (1894 p. 6) comments that "the numerous and extensive caves that honeycomb the makatea were formerly used as habitations, cemeteries, places of refuge, and stores. Scores of them are filled with dessicated human bodies". There are ten documented burial caves on the island of Atiu (Figure 1), however, limited knowledge of the range of Atiuan mortuary practices obscures the ancient socio-cultural implications of these cave burials.

'Rima' is five and 'Rau' is one hundred in the Atiuan language. So 'Te Ana Rima Rau' means 'the cave of five hundred dead'. Of the many oral legends about the origins of the burials, one recalls a famous battle involving 1000 Atiuan warriors, another a cannibal feast, and another about a story of revenge. Previously, we have provided an extensive report detailing the novel cave recording strategy that combined traditional cave survey techniques with bioarchaeological strategies (Clark et al. 2016). The aims of the current paper are twofold, to create a census of a sample of the skeletons and, to document evidence of oral health of the people represented.

\section{Origins of the Atiuans}

Direct archaeological and palaeoenvironmental evidence, including radiocarbon dates, indicates human arrival in the southern Cook Islands $\sim A D$ 1000-1225 (Allen and Wallace 2007; Kirch et al. 1995; Wilmshurst et al. 2011). Oral traditions note that the people arrived from Manuka (Manu'a, Samoa) (Gill 1876; Gudgeon 1904). According to Te Rangi Hīroa (Sir Peter Buck), the island of Atiu was discovered by Polynesians in the 1300s (Buck 1938) and Crocombe (1967) details a succession of 12 warrior chiefs prior to 1823. As removal of samples of human bone and teeth from the island was not permitted, ${ }^{14} \mathrm{C}$ radiocarbon dates from the human burials in Rima Rau cave are not available. Based on local oral histories and ${ }^{14} \mathrm{C}$ dates from the nearby island of Mangaia (Antón and Steadman 2003) it is probable that the cave was used as a burial site from at least the $14^{\text {th }}$ century. There is no evidence that its use postdates European contact.

The degree of prehistoric interaction among islands within the Southern Cooks is not well understood. However, there is traditional, ethnohistoric, ethnographic, and archaeological evidence for communication and trade between the islands (Buck 1971; Gill 1856-1880; Walter 1996). At the time of European contact, the three islands of Atiu, Ma'uke and Mitiaro were allied into the Nga Pu Toru polity (Kautai et al. 1984), where oral histories provide details of the Atiuan Rongomatane Ariki (high-chief) who lead "murderous cannibal raids" on the islands of Ma'uke and Mitiaro (Large 1913, p. 73). Oral traditions note that the Atiuan people were fierce warriors who demeaned their enemies after battle by cooking and 
eating their flesh (discussions with M Humphreys during field season, 2013). On the nearby island of Mangaia, $19^{\text {th }}$ century ethnohistorical accounts detail intense fighting over limited land and resources, which included interpersonal aggression, ritual sacrifice, and nutritive or ritual cannibalism (Gill 1894; Buck 1934). It is not known whether Atiuans endured similar resource hardships to Mangaia, but it is thought that environmental changes on Mangaia related to population growth associated with agricultural intensification likely led to such changes (Ellison 1994; Kirch et al. 1995).

The first contact from Europeans occurred with the visit by Captain James Cook's ships Resolution and Discovery on $31^{\text {st }}$ March 1777. Captain Cook estimated the population of Atiu to be at least 2000 (Beaglehole 1974). The next recorded contact with a European culture was made by missionaries in 1822 , where the population was estimated by Reverend John Williams (1837, p. 19) to be 'something under 2000'. Prior to European contact, the islanders lived in five communities around the island, on the lower ground adjacent to the swampy areas, and terraces were excavated for houses from the sides of the volcanic rock (Marshall 1930). In 1822, on the missionaries' instigation, the population was resettled on the central plateau of the island, in five contiguous villages reflecting the prehistoric communities. The boundaries of these villages are still recognised today (Crocombe 1967). The use of burial caves is thought to have ceased at the same time (Trotter 1974). Rapid reduction of the population followed European contact, largely as a result of the lack of immunity to western diseases (Parkes 1994). By 1842, there were only 985 islanders, in 1912 the population further dropped to 759, but by 1981 had increased to 1225 (Parkes 1997). In 2010, the population of Atiu was 511 as the island has recently seen the effects of depopulation of the working adult population, and now mostly comprises of children and older adults (Park and Littleton 2012).

\section{Materials}

The Rima Rau burial cave has a complex structure. The total floor area of the cave is roughly $190 \mathrm{~m}^{2}$, and it is approximately 28 metres long (Clark et al. 2016). Most of the skeletal remains observed in the cave were disarticulated and commingled, although several apparent partial or complete skeletons were present in the far reaches of the cave. We confined our research to human material that was easily accessible and disturbed by human or animal activity. The total number of skeletal elements recovered from the cave was 585, consisting of 451 adult elements and 134 subadult elements. The total number of teeth examined was 366 .

The full cave survey has been previously published in Clark et al. (2016), detailing the methods and procedures used for the removal, transport and reinternment of the human material from the cave burial site and the nearby field-laboratory. Because of the large number of skeletal remains within the cave and short six-week fieldwork period available, not all the skeletal remains were removed from these discrete areas, and in some areas of the cave, skeletal remains were not removed for analysis. Once the bones were analysed from one section of the cave they were returned to the area from which they came. A representative of the landowning family, Mr Punua Tauraa, carried out the process of repatriation of all of the skeletal remains to the cave and accompanied our team on all visits to the cave.

All taphonomic damage was differentiated from signs of stress and oral pathology. Many bones in the cave displayed evidence of postmortem breakage of unidentifiable cause. Some identifiable damage included marks from rodents, crabs and carnivores (such as a dog or pig). 


\section{Skeletal and Dental Recording Methods}

130 Because the remains analysed were disarticulated and commingled, a census of all the skeletal elements (complete or partial bones) was recorded, specifically detailing 'zones' of the skeletal elements in order to facilitate the assessment of the minimum number of individuals in the cave (Knüsel and Outram 2004). These are accepted procedures for commingled skeletal collections, particularly those subject to taphonomic damage. Using a zonal system allows for the differentiation of taphonomic damage and identification of specific areas of bone that were deliberately cut. This information may become relevant when interpreting mortuary practices within the skeletal assemblage (Outram et al. 2005).

The Minimum Number of Individuals (MNI) is a simple calculation of the minimum number from the recovered assemblage. However, Adams and Konigsberg (2008) recommend that the Most Likely Number of Individuals (MLNI) is also provided when dealing with commingled remains. This provides an estimate of the original number of individuals represented by the assemblage. This distinction is important in cases of bone loss due to taphonomic phenomena (Adams and Konigsberg 2008). Although both statistics are derived from the most frequently represented skeletal elements, the MLNI method accounts for taphonomic bias, it is therefore more accurate and provides a more realistic reconstruction of past population counts from commingled skeletal samples when recovery of the sample is less than 100\% (Adams and Konigsberg 2008). The MNI method uses the most repeated element of each side (Maximum [L or R]), where L signifies left and R signifies right. The MNI method assumes that infrequently observed elements are paired with more frequently observed elements. The MLNI formula (below) represents a maximum likelihood estimate. In contrast to the MNI, the MLNI considers the number of L (left) and R (right) elements in addition to those elements that can be matched as belonging to the same individual $(P)$ (Adams and Konigsberg 2008, p. 246).

$$
\text { MLNI }=\frac{(L+1)(R+1)}{(P+1)}-1
$$

Sex assessments for adult crania were carried out based on standard methods (Buikstra and Ubelaker 1994). No ancestry-specific methods exist for sex estimations from Polynesian crania. There is no means of assessing the sex of subadults. Dental wear and cranial suture closure was used to provide an approximation of age-at-death using accepted recording techniques (Buikstra and Ubelaker 1994). Although dental wear was graded using the recognised stages of occlusal wear in the molars, the degree of wear varies among populations based particularly on diet, so age estimates were based on relative wear within the sample and are accepted as approximations. Complete, defined as more than $75 \%$ of element present, uniquely identifiable cranial vaults and mandibles were selected to reduce any potential overrepresentation of age-at-death adult estimates. Age estimates for bones of infants and children ('subadults' less than 20 years of age) were determined by dental eruption patterns, epiphyseal fusion patterns, and metric analysis using standard methods (Buikstra and Ubelaker 1994; Scheuer and Black 2000). 
Pathological dental lesions were recorded using standardised dental anthropological recording methods (Hillson 2001, 2008), with some modifications referenced here. Eight oral pathologies were considered and except for enamel defects, are calculated per tooth/socket rather than per individual. Teeth were removed from their alveoli when possible for closer examination using a hand magnifier lens (x10). The recorded pathological conditions are: i) carious lesions, ii) periapical lesions, iii) antemortem tooth loss, iv) supragingival calculus, v) subgingival calculus, vi) alveolar resorption, vii) ante-mortem chipping of the occlusal edge, and viii) defects of dental enamel. The first three conditions are indicative of dental infection, with antemortem tooth loss (AMTL) as the final consequence of most dental disease. Calculus and alveolar resorption are associated with periodontal disease status.

Dental caries are a demineralisation of tooth enamel and dentine when acids are released from specific bacteria after metabolising cariogenic foods (Hillson, 2008). Carious lesions were considered present only if they were visibly cavitated and were recorded separately for all crown and root surfaces. No caries correction factors were calculated. Given the quality of the sample, this would have implied a degree of accuracy beyond that possible. Periapical lesions in the alveolar bone were recorded if observed macroscopically at the alveolar process closest to the socket (Hillson 2001, 2008). Such lesions may originate from infections of the pulp cavity, known as periapical dental abscess (Dias and Tayles, 1997). Differential diagnosis of such lesions was not attempted. Tooth loss prior to death (AMTL) was differentiated from postmortem tooth loss by evidence of remodelling of empty tooth sockets, and compared to the combined total of alveoli. No diagnosis of aetiology was attempted.

Mineralised or calcified dental plaque, known as dental calculus, was differentiated as either supra- or sub- gingival and severity measured occurring to Buikstra and Ubelaker (1994). The aetiology of calculus is multifactorial, and is influenced by diet, attrition, oral environment and saliva flow rate (Lieverse et al. 2007). Alveolar resorption is related to the loss of bone due to an inflammatory response of the gums during life, and is associated with periodontal disease (Hillson, 2008). Alveolar resorption was identified by textural changes in the interdental septum and scored according to degree of alveolar recession and exposure of tooth roots (none, slight, moderate and severe) (Kerr 1991, 1998). We were unable to apply modified clinical methods of classifying periodontal disease (e.g. Caton et al. 2018) as recordings were made per tooth, rather than per individual.

Enamel chipping may occur in food processing due to masticatory stress or through the use of teeth as occupational tools. These were recorded using the standards of Hillson (2008). All visible temporomandibular joint surfaces were examined for signs of bone degeneration, by surface, and by individual where identification was possible, to complete the range of oral pathologies.

Defects of dental enamel (DDE) are macroscopically visible lines, pits, grooves, or opacities on the tooth crown surface, and generally associated with a disruption during growth and development resulting from physiological stress (Clark 2018, Goodman and Rose, 1991). DDE were recorded according to type and region following methods outlined in Clark et al. (2014). Isolated teeth were not examined for DDE as to quantify systemic stress as it is essential to examine more than one tooth from an individual. As it was not possible to correlate mandible and maxilla to specific individuals, DDE was assessed for individuals by mandibles only in order to avoid potential overrepresentation. Statistical significance for all indicators of oral pathology was defined as $p<0.05$. 


\section{Minimum Number of Individuals}

The most frequently occurring bone was the adult parietal $(66 / 451,14.6 \%)$. Based on both the MNI and MLNI calculations of paired $(n=28)$, unpaired left $(n=33)$ and right $(n=31)$ adult parietal bones, there is a minimum of 38 adults in the sample. The most frequent subadult skeletal element is the mandible $(11 / 134,8.2 \%)$. From calculations of paired $(n=3)$, unpaired left $(n=5)$ and right $(n=6)$ subadult mandibles, the MNI is nine and MLNI is eight, providing a minimum number of eight subadults.

\section{Sex and Age Composition}

Of the adult skeletal elements from which sex could be assessed, the temporal bone was the most frequently represented (Table 2). The MNI calculated from these is 15 females and nine males. This represents a female-biased sex ratio of 5:3, with MNI of five unable to be estimated to either sex.

Age estimates from 33 adult cranial vaults with sutures, 21 maxillae with molars, and 30 mandibles with molars show all adult age groups (young, middle, old) were represented (Table 3). For 13 crania, both cranial suture closure and maxillary molar wear could be assessed. In six crania the estimates matched, in six dental wear provided a younger estimate than suture closure, and in one cranium dental wear provided an older estimate. Only one mandible and cranium were identified as belonging to the same adult male, with age estimates for cranial suture closure and mandible molar wear as middle age, but maxilla molar wear as young adult. The molar wear of the mandibular dentition was greater on average than for the maxillary dentition. Although no other crania were identified as positively matching a corresponding mandible, it is possible that other individuals are represented in both methods of age estimation and the disparity in wear patterns reflects the commingling of the remains.

Estimation of age-at-death for the eight subadults in the sample is difficult due to the absence of multiple bones identifiable as belonging to any one individual. Based on available evidence, the eight individuals are estimated to be one pre-term foetus of 24-25 weeks gestation, two full-term babies of 38-40 weeks, one 18 month old infant, one child aged 3-4 years, one 4-6 years and one 8 years old, together with one adolescent aged between 12 - 20 years.

\section{Oral Health}

The sample includes 918 alveoli (with and without teeth in situ) in addition to the 366 teeth. Table 4 summarises the prevalence of the three oral indicators associated with dental infection. Of 341 teeth for which carious lesions could be recorded, $12.6 \%$ were carious. Caries are significantly more prevalent on molars than on other tooth types (Table 4). Mandibular teeth had a higher frequency of caries compared with maxillary teeth, but this difference is not statistically significant. Caries were significantly more frequent on the root surfaces compared with the crown surfaces. The occlusal crown surface had a significantly higher frequency of caries than any other crown surface. No significant differences in caries rates were observed for the different root surfaces. Periapical cavities were uncommon, with only 15 observed (1.9\%). Despite the infrequency of such lesions, the periapical cavity for a young adult female was notably severe. As observed in Figure 2, the pathology can be 
identified by osteoblastic and osteoclastic activity, consistent with a bony response to infection affecting the anterior right maxilla with lesions penetrating into the maxillary sinus. Antemortem tooth loss (AMTL) occurred for $9.0 \%$ of teeth. AMTL is significantly more frequent with partial remodelling than with full remodelling of the alveolus.

Table 5 summarises the prevalence of the three oral indicators associated with periodontal disease, and antemortem chipping. A large proportion of teeth $(58.3 \%)$ were affected by supragingival calculus, which is significantly greater than the teeth affected by subgingival calculus (1.8\%). Supragingival calculus was significantly more frequently graded as mild, than moderate or severe. Alveolar resorption was observed in $12.5 \%$ of interalveolar septa, with a significantly greater frequency of moderate than mild. No severe resorption of the alveolar bone was observed. Antemortem chipping of the occlusal edge/surface was observed in $21.2 \%$ of teeth, and was directly associated with caries in two of those teeth. Enamel chipping occurs significantly more frequently in the molar teeth than the anterior teeth (Table 5).

Osteoarthritic changes to the temporomandibular joint (TMJ) in the form of pitting of the articular surfaces occur in $25 \%$ (10/40) of temporal joint surfaces. The mandibular condyles are unaffected except for one individual with unilateral degeneration. A minimum likely number of individuals with pathological TMJ surfaces is seven $(7 / 38,18.4 \%)$. Of the six individuals with age and sex estimates the condition was classified as severe for five individuals where both left and right joints were visible. This includes one middle-aged female, two young adult females, and two young adult males. For another young female the right TMJ was classified as slight, but the left side was severe.

Table 6 details the DDE per tooth and per individual. Almost $20 \%$ of observed teeth had DDE, with linear enamel hypoplasia observed significantly more frequently than other defect types. Of the four tooth types, DDE were most frequently observed on the canines. Twelve mandibles were suitable for individual analysis of DDE, representing six males, three females and three of indeterminate sex (including one adolescent). Significantly more males than females had DDE.

Five individuals $(5 / 12,41.7 \%)$ had localised defects observable in only one tooth. For two of these individuals the defects were singular linear enamel hypoplasia (LEH), the defects in two other individuals were discrete opacities in a single tooth, and one individual had one tooth with a diffuse opacity. Due to issues of preservation, wear and only considering mandibular teeth in the individual analysis, prevalence rates of localised enamel defects may not precisely reflect the frequency of traumatic events resulting in localised defects. For example, the single LEH defect in two of the five individuals may have resulted from systemic stress, rather than trauma. However, this cannot be determined with certainty due to a lack of defects in the rest of the mandibular dentition, but perhaps could have been resolved if corresponding maxillary teeth were observed.

Seven individuals $(7 / 12,58.3 \%)$ had DDE in at least two teeth (antimeres), indicating a systemic stressful event during childhood. Although the method of categorising periods of systemic stress developed by Clark et al. (2014) does not assign precise age ranges to timing of the defects, the technique is based on Littleton and Townsend (2005) who did attribute ageat-occurrence using data from modern Aborigine people from Central Australia. Systemic stress at Rima Rau most often occurred around the age when the crown of the mandibular premolars and second permanent molar were developing. From Littleton and Townsend (2005) the age at which systemic stress was experienced for the Rima Rau individuals can be quantified as follows: between 2.2-2.8 years (one adolescent), 2.8-4.0 years (one middle-aged male), 4.0-5.2 years (two middle-age males and one middle-aged female), and 9.0-12.0 years (one middle-aged male). Given the advanced dental development of modern Pacific Islanders 
and lack of population specific standards (Te Moananui et al. 2008), the age at stress occurrence provided above for Rima Rau is not a precise estimate.

\section{Discussion}

The census of the sample of disarticulated and commingled skeletal remains from the Rima Rau burial cave shows it includes a minimum of 38 adults representing all age groups and both sexes, although with a higher proportion of females than males, together with a minimum of eight subadults. Because of the degree of disturbance of burials, we were unable during the fieldwork to assess the total number of skeletons in the cave, and therefore have no means of determining how representative our sample may be of the full complement of burials. The imbalanced sex ratio may therefore well be a reflection of the nature of our sample rather than indicating that more women than men were buried in the cave. It is unlikely to be an error in the method used. Similarly, the sample composition may be contributing to the apparent inconsistency in estimates of age at death between cranial suture closure and dental wear within the sample. Both methods of age estimation are acknowledged to have issues with their application (Mays 2015). The progression of cranial suture closure is highly variable among individuals and is generally a method of last resort when estimating age at death. Dental wear is also potentially variable among individuals as it is clearly dependent on diet, together with numerous other factors such as malocclusion and bruxism also having an effect.

The study of oral disease provides an essential factor in exploring the overall health, wellbeing, and daily life experiences of people in the past. Prior to antibiotics, dental infections could have resulted in life threatening conditions, and affected an individual's longevity. Figure 3 provides an example of oral pathologies observed in the Rima Rau sample. The patterning of oral health is multifactorial, and unfortunately many factors cannot be examined in an archaeological situation such as this where we have no other information on context such as subsistence patterns, diet, nutrition, and disease load. Agents relevant to this study of oral health include fertility patterns and sex differences (Lukacs 2011), oral hygiene behaviours, oral bacteria diversity and load, and of course, diet and food preparation methods. However, some discussion of oral disease in the past can be made through a comparison of the frequencies of oral health pathologies from other Polynesian archaeological skeletal samples (Table 7), with the caveat that the data are affected by the chronological age of the sites, together with sample size, age-at-death and sex composition. The data therefore provide a generalised comparison rather than allowing detailed analysis of patterns and causes of similarities and differences.

Caries in the Rima Rau sample are more likely to be observed on the roots and occlusal surface, which aligns with the expectation that the cementoenamel junction and occlusal surface fissures hold plaque (Neuhaus 2018). Within prehistoric Polynesia, frequencies of caries range from $4.8 \%$ (Wairau Bar) to $27.1 \%$ (Rapa Nui), with the frequency for Rima Rau of $12.6 \%$ falling within the moderate range similar to the frequencies reported at 'Atele (13.5\%) and Honokahua (13.5\%).

Periapical lesions from the Rima Rau sample are within the range recorded from other sites in tropical Polynesia, which are all very low compared to early New Zealand Māori where $18 \%$ of teeth had associated periapical lesions (Kieser et al. (2001) and 11.5\% at Wairau Bar (Buckley et al. 2010). The latter are attributed to severe occlusal wear, exposing the pulp cavity to infection. As Houghton (1996) notes, foods within the tropical regions of the Pacific tend to be softer compared with prehistoric New Zealand with corresponding lower rates of occlusal wear . 
Antemortem tooth loss can be the final consequence of most dental diseases. Within prehistoric Polynesia, the frequency of AMTL ranges from 3.3\% (Hane dune) to $9.6 \%$ (Honokahua), with the AMTL frequency of $7.7 \%$ in the Rima Rau sample, within the range. Stantis (2015) attributes the 6.3\% AMTL frequency at 'Atele to dental trauma resulting from the consumption of marine foods (such as shellfish) indicated by high nitrogen isotope values. The frequency of enamel chipping at 'Atele was $17.3 \%$, which is similar to Rima Rau at $21.2 \%$. Although nitrogen isotopic values are unavailable for the Rima Rau sample, marine foods would have formed a substantial part of the diet, resulting in dental trauma and ultimately tooth loss as observed in prehistoric Tonga. At Rima Rau, the partial remodelling of the alveoli in majority of tooth sockets observed with AMTL suggests tooth loss was recently before death.

The dental chipping at Rima Rau tended to be small in size $(\leq 1 \mathrm{~mm})$ and originating on the occlusal surface, suggestive of chipping caused by tough food particles rather than personal injury such as falling or interpersonal violence (Lukacs, 2007; Scott and Winn, 2011). Hillson's (2001) recording scheme for recording dental chipping does not include recording size or number of chips on the tooth, an approach that should perhaps be altered in future dental data collection. The authors recorded no chips of especially large size in the Rima Rau collection.

Conditions relating to periodontal health at Rima Rau are reflected in high rates of mild supragingival calculus but relatively low rates of alveolar resorption and subgingival calculus compared to other Polynesian sites (Table 7). This pattern of calculus is consistent with observations by Stantis et al (2016) from Tonga. Again, as Houghton (1996) observes that along with the pattern of light wear, slight calculus and light periodontal disease is relatively common across the prehistoric tropical Pacific.

The high incidence of pathological changes in the TMJ both at the surface count and individual levels appears to be at odds with the suggestion of low tooth wear but has been associated with extensive enamel chipping in the molar teeth elsewhere in early Pacific cultures (Nelson et al. 2016). The degenerative changes of the TMJ are also consistent with the level of tooth wear observed in the sample attributed to high biting force, for either dietary or non-dietary reasons (Nelson et al. 2016). The latter has been cited as a possible reason for severe TMJ degeneration in males at the site of Sigatoka, Fiji (Visser 1995: 115 cited in Houghton 1996), where kava chewing is a possible explanation, although the uncertainty about the rate of dental wear in the sample confounds this interpretation for Rima Rau.

Nearly $60 \%$ of individuals represented by a mandible had DDE, which is comparable to over $70 \%$ of prehistoric Māori from Wairau Bar (Buckey et al. 2010). As observed at Wairau Bar, a higher proportion of Rima Rau males were affected by DDE compared to females. Such dental evidence of systemic stress indicates that growth disruptions were common during early childhood. Although both sexes were affected, males were more susceptible to stress owing to inherent genetic differences or different socioenvironmental stresses were suffered by boys and girls. During our time in Atiu, we heard the oral history that when boys were born, they were wrapped in taro leaves and placed on the marae overnight. If the baby boy broke free of the leaves before morning, he was destined to be warrior, if the leaves remained unbroken he became a farmer (discussions with P Tauraa during field season, 2013). This example of prehistoric cultural practices highlights sexspecific behaviours that may result in stress differences between the sexes observed in the teeth. Nevertheless, the high levels of systemic stress shown in the teeth may indicate that the Rima Rau people were survivors of the biosocial stresses during childhood, and some lived into old age. 


\section{Conclusion}

This paper is the first bioarchaeological investigation of prehistoric islanders of Atiu. We have developed a census of a sample of the disarticulated and commingled human skeletal remains from the Rima Rau burial cave, and provided an assessment of oral health. This shows that the people buried in the cave had moderate rates of dental caries and supragingival calculus combined with relatively low rates of periodontal disease and periapical cavities. TMJ degeneration is high despite relatively low levels of occlusal wear. The high prevalence of DDE, shows that the population was subject to growth disruption during childhood but also suggests that those who survived to adulthood were robust enough to withstand these periods of early life stress. Interpreting this complex pattern of oral health is complicated by our inability to confidently assess age at death, confounding interpretation of age-related oral health conditions in the disarticulated, commingled and possibly unrepresentative sample.

\section{Acknowledgements}

We thank the editors and reviewers for their careful reading of our manuscript and thoughtful comments. We sincerely thank the family landowners, Eugene Tatuava, Kore Samuela, and Punua Tauraa for inviting us to carry out this project. A very special thank you to Punua Tauraa for his invaluable assistance. We thank the Cook Islands National Research Council, Office of the Prime Minister, Rarotonga for permission to undertake the research (Permit no. 13/13). Thanks to Atiu Mayor Taoro Brown, and the CEO of the Island Council, Teariki Maurangi, and Marshall Humphreys with the fieldwork organisation. We thank Gerald McCormack, Cook Islands Natural Heritage Project, for his advice on the project. We were shown great kindness, generosity and hospitality during our visit from the whole island community. Finally, we would like to acknowledge and pay our respects to the ancestors interred within Te Ana Rima Rau.

\section{References}

Adams BJ, Konigsberg LW. 2008. How many people? Determining the number of individuals represented by commingled remains. In: Adams BJ, Byrd, JE, editors. Recovery, analysis, and identification of commingled human remains. Dordrect (Netherlands): Springer. p. 241-256.

Allen, MS, Wallace R. 2007. New evidence from the East Polynesian gateway: substantive and methodological results from Aitutaki, Southern Cook Islands. Radiocarbon. 49(3):1163-1179.

Antón SC, Steadman DW. 2003. Mortuary patterns in burial caves on Mangaia, Cook Islands. Int J Osteoarchaeol. 13(3):132-146.

Beaglehole JC. 1974. The life of Captain James Cook. Stanford (CA): Stanford University Press.

Buck PH (Te Rangi Hīroa). 1934. Mangaian Society. Honolulu (HI): Bernice P. Bishop Museum Bulletin 122.

Buck PH. (Te Rangi Hīroa). 1938. Vikings of the sunrise. Philadelphia (PA): Lippincott. 
Buck PH. (Te Rangi Hīroa). 1971. An introduction to Polynesian anthropology. Honolulu (HI): Bernice P. Bishop Museum

Buckley HR, Tayles N, Halcrow SE, Robb K, Fyfe R. 2010. The people of Wairau Bar: a Reexamination. J Pac Archaeol. 1(1):1-20.

Buikstra JE, Ubelaker DH. 1994. Standards for data collection from human skeletal remains: Fayetteville, AR: Arkansas Archaeological Survey. Proceedings of a seminar at the field museum of natural history, Arkansas Archaeological Survey Research Series No. 44.

Caton JG, Armitage G, Berglundh T, Chapple ILC, Jepsen S, Kornman KS, Mealey BL, Papapanou PN, Sanz M, Tonetti MS. 2018. A new classification scheme for periodontal and peri-implant diseases and conditions - Introduction and key changes from the 1999 classification. J Clin Periodontol. 45(suppl 20):S1-S8.

Clark AL. 2018. Physiological Stress. In: Trevathan W, editor-in-chief. The International Encyclopaedia of Biological Anthropology. Hoboken (NJ): Wiley

Clark, AL, Tayles N, Halcrow SE. 2014. Aspects of health in prehistoric mainland Southeast Asia: Indicators of stress in response to the intensification of rice agriculture. Am J Phys Anthropol. 153(3):484-495.

Clark AL, Tayles N, Buckley HR, Neuman F. 2016. The Rima Rau Burial Cave, Atiu, Cook Islands. JICA.11(1), pp.68-88.

Collins SL, Weisler MI. 2000. Human dental and skeletal remains from Henderson Island, southeast Polynesia. People and Culture in Oceania. 16:67-85.

Crocombe RG. 1967. From ascendancy to dependency: the politics of Atiu. J Pac Hist. 2(1):97-111.

Dias G, Tayles, N. 1997. ‘Abscess cavity' - a misnomer. Int J Osteoarchaeol. 7(5):548-554

Dickinson WR. 1998. Geomorphology and geodynamics of the Cook-Austral Islandseamount chain in the South Pacific Ocean: implications for hotspots and plumes. Int Geol Rev. 40(12):1039-1075.

Ellison JC. 1994. Caves and speleogenesis of Mangaia, Cook Islands. Atoll Res Bull. 417:125

Franklin J, Steadman DW. 1991. The potential for conservation of Polynesian birds through habitat mapping and species translocation. Conserv Biol. 5(4):506-521.

Gill WW. 1856. Gems from the coral islands. London (UK): Ward \& Co.

Gill WW. 1876. Life in the southern isles; or, scenes and incidents in the South Pacific and New Guinea. London (UK): Religious Tract Society.

Gill WW. 1880. Historical sketches of savage life in Polynesia. Wellington (NZ): George Didsbury, Govt. Printer. 
Gill WW. 1894. From darkness to light in Polynesia. London (UK): The Religious Tract Society.

Goodman AH, Rose JC. 1991. Enamel hypoplasias as indicators of nutritional status. In: Kelley MA, Larsen CS, editors. Advances in dental anthropology. New York (NY): Wiley-Liss. p. 279-293.

Gruning EL. 1937. Notes on burial caves in the Cook Group, South Pacific. Ethnol Cranmorensis. 1:21-25.

Gudgeon WE. 1904. Phallic emblem from Atiu Island. J Polyn Soc. 13(4):210-212.

Hillson S. 2001. Recording dental caries in archaeological human remains. Int J Osteoarchaeol. 11(4):249-289.

Hillson S. 2008. Dental pathology. In: Katzenberg MA, Saunders SR, editors. Biological anthropology of the human skeleton. $2^{\text {nd }}$ edition. Hoboken (NJ): Wiley-Liss. p.301-340

Houghton P. 1996. People of the great ocean: aspects of human biology of the early Pacific. Cambridge (UK): Cambridge University Press.

Kautai N. 1984. Atiu: An Island Community. Suva (Fiji): Institute of Pacific Studies of the University of the South Pacific in association with the Cook Islands Ministry of Education and the Atiu Island Trust.

Keene HJ. 1986. Dental caries prevalence in early Polynesians from the Hawaiian Islands. J Dent Res. 65(6):935-938.

Kerr NW. 1991. Prevalence and natural-history of periodontal-disease in Scotland - the Medieval period (900-1600 AD). J Periodontal Res. 26(4):346-354.

Kerr NW. 1998. Prevalence and natural history of periodontal disease in prehistoric Scots (pre-900 AD). J Periodontal Res. 33(3):131-137.

Kieser JA, Kelsen A, Love R, Herbison PGP, Dennison KJ. 2001. Periapical lesions and dental wear in the early Māori. Int J Osteoarchaeol. 11(4):290-297.

Kirch PV, Steadman DW, Butler VL, Hather, J, Weisler MI. 1995. Prehistory and Human Ecology in Eastern Polynesia: Excavations at Tangatatau Rockshelter, Mangaia, Cook Islands. Archaeol Ocean. 30(2):47-65.

Knüsel CJ, Outram AK. 2004. Fragmentation: the zonation method applied to fragmented human remains from archaeological and forensic contexts. Environ Archaeol. 9(1):85-98.

Large JT. 1913. Some notes on Atiu Island, Cook Group, South Pacific. J Polyn Soc. 22(2 (86)):67-76.

Lowe DJ, Gunn J. 1986. Caves and limestones of the islands of Tongatapu and 'Eua, Kingdom of Tonga. Cave Sci. 13(3):105-130.

Lukacs JR. 2007. Dental trauma and antemortem tooth loss in prehistoric Canary Islanders: prevalence and contributing factors. Int. J. Osteoarchaeol., 17: 157-173. 
Lukacs JR. 2011. Sex differences in dental caries experience: clinical evidence, complex etiology. Clin Oral Investig. 15(5):649-656.

Lieverse A, Link D, Bazaliiskiy V. 2007. Dental health indicators of hunter-gatherer adaptation and cultural change in Siberia's Cis-Baika. Am J Phys Anthropol. 134(3):323339.

Littleton J, Townsend G. 2005. Linear enamel hypoplasia and historical change in a central Australian community. Aust Dent J. 50(2):101-107.

Mana NT, Tereroa Cameron, Koronui N, Tanga M, George T, Rau T, Mariri T, Bob NK. 1984. Historical sites. In: Kura P, Institute of Pacific Studies University of the South Pacific, South Pacific Creative Arts Society, Atiu Island Trust and Cook Islands. Ministry of Education (editors). Atiu Nui Maruarua: E Au Tua Ta'ito. Suva, Fiji : Institute of Pacific Studies of the University of the South Pacific, in association with South Pacific Creative Arts Society, Cook Islands Ministry of Education and Atiu Island Trust; p.5866.

Marshall P. 1930. Geology of Rarotonga and Atiu. Honolulu (HI): Bernice P. Bishop Museum.

Mays SA. 2015. The effect of factors other than age upon skeletal age indicators in the adult. Ann Hum Biol. 42(4):32-341.

Mueller-Dombois D, Fosberg FR. 1998. Vegetation of the Tropical Pacific Islands. New York (NY): Springer.

Nelson GC, Stone JH, Fitzpatrick SM. 2016. Adapting to Palau. In: Oxenham M, Buckley, HR, editors. The Routledge Handbook of Bioarchaeology in Southeast Asia and the Pacific Islands. London (UK): Routledge. p.502-526

Neuhaus KW. 2018. Detection of occlusal caries. In: Bekes, K, editor. Pit and Fissure Sealants. Cham (Switzerland): Springer. p. 51-67.

Nunn, PD. 1994. Oceanic islands. Oxford (UK): Blackwell.

Outram AK, Knüsel CJ, Knight S, Harding AF. 2005. Understanding complex fragmented assemblages of human and animal remains: a fully integrated approach. J Archaeol Sci. 32(12):1699-1710.

Owsley DW, Miles AM, Gill GW. 1985. Carious lesions in permanent dentitions of prehistoric Easter Islanders. J Poly Soc. 94(4):415-422

Park JK, Littleton J. 2012. Report on two research visits to Atiu, Cook Islands, 2010 and 2011. Auckland (NZ): Department of Anthropology, The University of Auckland. Report No 1. "Transnational Pacific Health through the lens of tuberculosis" Research Group. p. $1-47$

Parkes A. 1994. Holocene environments and vegetational change on four Polynesian islands [PhD dissertation]. Hull (UK): The University of Hull 
Parkes A. 1997. Environmental change and the impact of Polynesian colonization: sedimentary records from central Polynesia. In: Kirch PV, Hunt TL, editors. Historical Ecology in the Pacific Islands. New Haven (CT): Yale University Press. p. 166-199.

Pietrusewsky M, Douglas MT, Ikehara-Quebral RM, Lauer KK. 2019. Skeletal and dental health of early Tongans: the bioarchaeology of the human skeletons from the To-At-36 site, Ha'ateiho, Tongatapu, Tonga. JICA. [accessed 2019 Jun 24] https://doi.org/10.1080/15564894.2018.1564711

Scheuer L, Black SM. 2000. Developmental Juvenile Osteology. San Diego (CA): Academic Press.

Scott EC. 1979. Dental wear scoring technique. Am. J. Phys. Anthropol., 51: 213-217.

Scott GR, Winn JR. 2011. Dental chipping: Contrasting patterns of microtrauma in Inuit and European populations. Int. J. Osteoarchaeol., 21: 723-731.

Stantis C. 2015. Diet and migration in prehistoric remote Oceania [PhD dissertation]. Dunedin (NZ): University of Otago.

Stantis C, Tayles, N, Kinaston RL, Cameron C, Nunn PD, Richards MP, Buckley HR. 2016. Diet and subsistence in remote oceania: an analysis using oral indicators of diet. In: Oxenham M, Buckley, HR, editors. The Routledge Handbook of Bioarchaeology in Southeast Asia and the Pacific Islands. London (UK): Routledge. p.569-598.

Steadman DW. 1991. Extinct and extirpated birds from Aitutaki and Atiu, Southern Cook Islands. Pac Sci. 45(4):325-347.

Steadman DW, Bollt R. 2010. Prehistoric birds from Rurutu, Austral Islands, East Polynesia. Pac Sci. 64(2):315-325.

Stefan VH, Collins SL, Weisler MI. 2002. Henderson Island crania and their implication for southeastern Polynesian prehistory. J Polyn Soc. 111(4):371-383.

Stoddart DR, Gibbs PE. 1975. Almost-atoll of Aitutaki: reef studies in the Cook Islands, South Pacific. Atoll Res Bull. 190:1-235.

Stoddart DR, Spencer T. 1987. Rurutu reconsidered: the development of makatea topography in the Austral Islands. Atoll Res Bull. 297:1-19.

Tangatapoto V. 1984. Mate: Death. In: Kura P, Institute of Pacific Studies University of the South Pacific, South Pacific Creative Arts Society, Atiu Island Trust and Cook Islands. Ministry of Education (editors). Atiu Nui Maruarua: E Au Tua Ta'ito. Suva, Fiji : Institute of Pacific Studies of the University of the South Pacific, in association with South Pacific Creative Arts Society, Cook Islands Ministry of Education and Atiu Island Trust; p. 147-157.

Taylor RMS. 1962. Non-metrical studies of the human palate and dentition in Moriori and Māori skulls: Part 2. J Poly Soc. 71(2):167-187.

Te Moananui R, Kieser JA, Herbison P, Liversidge HM. 2008. Advanced dental maturation in New Zealand Māori and Pacific Island children. Am J Hum Biol. 20(1):43-50 
Teiotu U. 2007. Te Kakau Rangatira = clothing of the chiefs. Rarotonga (CI): Atiu Are Ta'unga

Trotter MM. 1974. Archaeological survey of Atiu, Cook Islands. In: Trotter MM, editor. Prehistory of the Southern Cook Islands. Christchurch (NZ): Canterbury Museum Trust Board; p. 95-119.

Trotter MM. 1979. Niue Island archaeological survey. Christchurch (NZ): Canterbury Museum Trust Board.

Vacher HL. 2004. Introduction: varieties of carbonate islands and a historical perspective. In: Vacher, HL, Quinn TM, editors. Geology and hydrogeology of carbonate islands. Amsterdam (The Netherlands): Elsevier Science; p.1-33

Walter R. 1996. Settlement pattern archaeology in the southern Cook Islands: a review. J Polyn Soc. 105(1):63-99.

Williams J. 1837. A narrative of missionary enterprises in the South Sea Islands. London (UK): John Snow \& Co.

Wilmshurst JM, Hunt T1, Lipo CP, Anderson AJ. 2011. High-precision radiocarbon dating shows recent and rapid initial human colonization of East Polynesia. Proc Natl Acad Sci U S A. 108(5):1815-1820.

Wood BL, Hay RF. 1970. Geology of the Cook Islands. Wellington: Department of Scientific and Industrial Research, New Zealand.

\section{Figure captions}

Figure 1. Map of the Pacific, Southern Cook Islands and Atiu showing the locations of islands and places mentioned in this paper. Locations of the caves on Atiu from Steadman (1991) and Trotter (1974).

Figure 2a. Inferior view of maxilla. Periapical cavity in a young adult female. Pathological bone changes are consistent with a response to infection affecting the anterior right maxilla with lesions penetrating into the right maxillary sinus (indicated by white arrows).

Figure 2b. Frontal view of maxilla. Periapical cavity in a young adult female. Pathological bone changes are consistent with a response to infection affecting the anterior right maxilla with lesions penetrating into the right maxillary sinus (indicated by white arrows).

Figure 3. Lateral left view of cranium. Periapical cavity on upper left first permanent molar for a young adult female (indicated by black arrow). Oral pathology for tooth 16 and 17 also includes severe alveolar resorption, slight calculus, and a large buccal root caries on tooth 16 (indicated by white arrow). Antemortem tooth loss observed for tooth 18. 
628 


\section{Tables}

Table 1. The presence and use of burial caves on the makatea islands of Polynesia

\begin{tabular}{|c|c|c|c|c|c|c|c|}
\hline Name and Location & $\begin{array}{l}\text { Size } \\
\left(\mathrm{km}^{2}\right)\end{array}$ & $\begin{array}{c}\text { Historic } \\
\text { Account of } \\
\text { Burial Cave/s }\end{array}$ & $\begin{array}{c}\text { Minimum } \\
\text { Number of } \\
\text { Burial Caves } \\
\end{array}$ & $\begin{array}{c}\text { Archaeological } \\
\text { Examination of } \\
\text { Burial Caves }\end{array}$ & $\begin{array}{l}\text { Osteological } \\
\text { Analyses }\end{array}$ & $\mathrm{MNI}^{1}$ & Reference \\
\hline Atiu, southern Cook Islands & 29.0 & Yes & 7 & Yes & No & 36 & $\begin{array}{l}\text { Gruning 1937; Large 1913; Steadman 1991; Tangatapoto } \\
\text { 1984; Trotter 1974; Walter } 1996\end{array}$ \\
\hline Mangaia, southern Cook Islands & 52.0 & Yes & 4 & Yes & Yes & 92 & Antón and Steadman 2003; Ellison 1994 \\
\hline Ma'uke, southern Cook Islands & 18.4 & Yes & Unknown & No & No & $\mathrm{N} / \mathrm{A}$ & Large 1913; Walter 1996 \\
\hline Mitiaro, Southern Cook Islands & 22.3 & Yes & Unknown & No & No & N/A & Franklin and Steadman 1991; Walter 1996 \\
\hline Rurutu, Austral Islands & 38.5 & No & Unknown & No & No & $\mathrm{N} / \mathrm{A}$ & $\begin{array}{l}\text { Dickinson 1998; Nunn 1994; Stoddart and Spencer 1987; } \\
\text { Steadman and Bollt } 2010\end{array}$ \\
\hline Rimatara, Austral Islands & 9.0 & No & Unknown & No & No & N/A & Dickinson 1998 \\
\hline Henderson, Pitcairn Group & 37.3 & Yes & 4 & Yes & Yes & 17 & Collins and Weisler 2000; Stefan et al. 2002 \\
\hline Niue, Western Polynesia & 259.0 & Yes & 59 & Yes & Limited & 300 & Trotter 1979 \\
\hline Makatea, Tuamotu Archipelago & 24.0 & No & Unknown & No & No & N/A & Mueller-Dombois and Fosberg 1998; Wood and Hay 1970 \\
\hline Tongatapu, Tongan Archipelago & 259.0 & $\mathrm{No}^{2}$ & Unknown & No & No & N/A & Lowe and Gunn 1986; Stoddart and Gibbs 1975; Vacher 2004 \\
\hline 'Eua, Tongan Archipelago & 81.0 & $\mathrm{No}^{2}$ & Unknown & No & No & $\mathrm{N} / \mathrm{A}$ & Lowe and Gunn 1986; Mueller-Dombois and Fosberg 1998 \\
\hline
\end{tabular}

${ }^{1} \mathrm{MNI}$ is the minimum number of individuals based on the references provided (MNI for Atiu excludes results results from Te Ana Rima Rau)

2 The presence of burial caves are noted in passing in Lowe and Gunn (1986: 106), but were not documented during cave surveys 
Table 2. Sex Assessment of adult Temporal Bones $(n=53)$ from Rima Rau Burial Cave Sample

\begin{tabular}{lcccc}
\hline \multicolumn{1}{c}{ Sex Assessment } & $\begin{array}{c}\text { Paired } \\
\text { Left and Right }\end{array}$ & $\begin{array}{c}\text { Unpaired } \\
\text { Left }\end{array}$ & $\begin{array}{c}\text { Unpaired } \\
\text { Right }\end{array}$ & $\begin{array}{c}\text { MNI } \\
\text { (Max } \boldsymbol{L} \text { or } \boldsymbol{R} \text { ) }\end{array}$ \\
\hline Female or & 9 & 4 & 6 & 15 \\
Probable Females & 0 & 3 & 5 & 5 \\
Indeterminate & 3 & 6 & 5 & 9 \\
Males or & & & & \\
Probable Males & & & & \\
\hline
\end{tabular}

Table 3. Adult Age-at-Death Assessment of Cranial Vault Elements $(n=33)$, Maxilla $(n=$ $21)$ and Mandibles $(n=30)$ from Rima Rau Burial Cave Sample*

\begin{tabular}{lccc}
\hline \multicolumn{1}{c}{ Age-at-Death Assessment } & $\begin{array}{c}\text { Cranial Suture } \\
\text { Closure }\end{array}$ & $\begin{array}{c}\text { Maxillary Molar } \\
\text { Wear }\end{array}$ & $\begin{array}{c}\text { Mandibular Molar } \\
\text { Wear }\end{array}$ \\
\hline Young Adult (20-35 years) & 12 & 10 & 9 \\
Middle Adult (35-50 years) & 15 & 9 & 12 \\
Old Adult (50+ years) & 6 & 2 & 9 \\
TOTAL & 33 & 21 & 30 \\
\hline
\end{tabular}

* based on Buikstra and Uberlaker (1994) 
Table 4. Frequencies of dental caries, periapical cavities, and antemortem tooth loss (AMTL) for the Rima Rau Burial Cave Sample, (reported by tooth/alveolus)

\begin{tabular}{|c|c|c|c|}
\hline Oral Pathology & $A / O$ & $\%$ & $p$-value \\
\hline Caries & $43 / 341$ & 12.6 & \\
\hline Dental $\operatorname{arch}^{1}$ & & & $<0.001$ \\
\hline - anterior teeth & $3 / 109$ & 2.8 & \\
\hline - molars & $40 / 232$ & 17.2 & \\
\hline$J_{a w}^{2}$ & & & 0.613 \\
\hline - maxillary & $17 / 147$ & 11.6 & \\
\hline - mandibular & $26 / 194$ & 13.4 & \\
\hline Tooth Region ${ }^{3}$ & & & 0.027 \\
\hline - crown & $56 / 1533$ & 3.8 & \\
\hline - root & $64 / 1184$ & 5.7 & \\
\hline Crown Surface 4 & & & $<0.001$ \\
\hline - occlusal & $13 / 342$ & 3.8 & \\
\hline - buccal & $5 / 294$ & 1.7 & \\
\hline - distal & $7 / 303$ & 2.3 & \\
\hline - lingual & $5 / 298$ & 1.7 & \\
\hline - mesial & $26 / 296$ & 2.0 & \\
\hline Root Surface 5 & & & 0.220 \\
\hline - buccal root & $22 / 296$ & 7.4 & \\
\hline - distal root & $17 / 295$ & 5.8 & \\
\hline - lingual root & $11 / 298$ & 3.7 & \\
\hline - mesial root & $14 / 295$ & 4.7 & \\
\hline Periapical Cavities & $15 / 803$ & 1.9 & - \\
\hline AMTL 6 & $71 / 918$ & 7.7 & 0.002 \\
\hline - Tooth lost, with partial remodelling & $48 / 918$ & 5.2 & \\
\hline - Tooth lost, with full remodelling & $23 / 918$ & 2.5 & \\
\hline
\end{tabular}

${ }^{1} \chi^{2}(2)=12.84$

${ }^{2} \chi^{2}(2)=0.256$

${ }^{3} \chi^{2}(2)=0.027$

${ }^{4} \chi^{2}(5)=24.214$

${ }^{5} \chi^{2}(4)=4.420$

${ }^{6} \chi^{2}(2)=9.157$ 
Table 5. Frequencies of calculus, alveolar resorption and antemortem chipping for the Rima Rau Burial Cave Sample (reported by tooth/tooth socket)

\begin{tabular}{|c|c|c|c|}
\hline Oral Pathology & $A / 0$ & $\%$ & $p$-value \\
\hline Supragingival Calculus ${ }^{1}$ & $196 / 336$ & $58.3^{*}$ & $<0.001$ \\
\hline - Mild & $176 / 336$ & 52.4 & \\
\hline - Moderate & $20 / 336$ & 6.0 & \\
\hline - Severe & $0 / 336$ & 0.0 & \\
\hline Subgingival Calculus ${ }^{2}$ & $6 / 336$ & 1.8 & 0.101 \\
\hline - Mild & $5 / 336$ & 1.5 & \\
\hline - Moderate & $1 / 336$ & 0.3 & \\
\hline - Severe & $0 / 336$ & 0.0 & \\
\hline Alveolar Resorption ${ }^{3}$ & $50 / 400$ & 12.5 & 0.019 \\
\hline - Mild & $17 / 400$ & 4.3 & \\
\hline - Moderate & $33 / 400$ & 8.3 & \\
\hline - Severe & $0 / 400$ & 0.0 & \\
\hline Antemortem Chipping ${ }^{4}$ & $71 / 335$ & 21.2 & $<0.001$ \\
\hline - not associated with caries & $69 / 335$ & 20.6 & \\
\hline - associated with caries & $2 / 335$ & 0.6 & \\
\hline Dental $\operatorname{arch}^{5}$ & & & 0.023 \\
\hline - permanent anterior teeth (incisors, & $34 / 198$ & 17.2 & \\
\hline canines, premolars) & $33 / 118$ & 28.0 & \\
\hline - permanent molars & & & \\
\hline
\end{tabular}

$* \chi^{2}(2)=255.52, \mathrm{p}<0.001$

${ }^{1} \chi^{2}(2)=175.29$

${ }^{2} \chi^{2}(2)=2.69$

${ }^{3} \chi^{2}(2)=5.46$

${ }^{4} \chi^{2}(2)=70.72$

${ }^{5} \chi^{2}(2)=5.16$ 
Table 6. Frequencies of defects of dental enamel for the Rima Rau Burial Cave Sample, reported by tooth and per individual

\begin{tabular}{|c|c|c|c|}
\hline Oral Pathology & $\mathrm{A} / \mathrm{O}$ & $\%$ & $p$-value \\
\hline \multicolumn{4}{|l|}{ By Tooth } \\
\hline Defect Type ${ }^{1}$ & $47 / 239$ & 19.7 & 0.001 \\
\hline - Horizontal linear grooves & $33 / 239$ & 13.8 & \\
\hline - Vertical linear grooves & $1 / 239$ & 0.4 & \\
\hline - Pitting & $1 / 239$ & 0.4 & \\
\hline - Discrete opacities & $5 / 239$ & 2.1 & \\
\hline - Diffuse opacities & $7 / 239$ & 2.9 & \\
\hline \multicolumn{4}{|l|}{ Tooth Type ${ }^{2}$} \\
\hline - Incisors & $5 / 29$ & 17.2 & 0.054 \\
\hline - Canines & $14 / 40$ & 35.0 & \\
\hline - Premolars & $12 / 84$ & 14.3 & \\
\hline - Molars & $16 / 86$ & 18.6 & \\
\hline \multicolumn{4}{|l|}{ By Individual } \\
\hline $\operatorname{Sex}^{3}$ & $12 / 38$ & 23.7 & 0.022 \\
\hline Males & $6 / 9$ & 66.7 & \\
\hline Females & $3 / 15$ & 20.0 & \\
\hline Indeterminate & $3 / 5$ & 20.0 & \\
\hline Stress Type 4 & & & 0.414 \\
\hline Localised defects (only one-tooth) & $5 / 12$ & 41.7 & \\
\hline Systemic stress (at least two teeth) & $7 / 12$ & 58.3 & \\
\hline
\end{tabular}

${ }^{1} \chi^{2}(5)=80.09$

$2 \chi^{2}(4)=7.67$

${ }^{3} \chi^{2}(2)=5.23$

${ }^{4} \chi^{2}(2)=0.67$ 
Table 7. Comparative oral pathology frequency data (\%) for Rima Rau and other Polynesian samples

\begin{tabular}{|c|c|c|c|c|c|c|c|}
\hline $\begin{array}{c}\text { Skeletal } \\
\text { Assemblage }\end{array}$ & $\begin{array}{l}\text { Dental } \\
\text { Caries }\end{array}$ & $\begin{array}{l}\text { Periapical } \\
\text { Cavities }\end{array}$ & AMTL & Calculus & $\begin{array}{c}\text { Alveolar } \\
\text { Resorption }\end{array}$ & Chipping & Reference \\
\hline $\begin{array}{l}\text { Rima Rau, Atiu, } \\
\text { Cook Islands }\end{array}$ & 12.6 & 1.9 & 7.7 & 58.3 & 12.5 & 21.2 & This study \\
\hline $\begin{array}{l}\text { Hane dune, } \\
\text { Marquesas }\end{array}$ & 5.4 & 1.8 & 3.3 & 19.9 & 32.4 & & $\begin{array}{l}\text { Pietrusewsky et al. } \\
1976 \text { cited in } \\
\text { Pietrusewsky et al. } \\
2019\end{array}$ \\
\hline $\begin{array}{l}\text { ‘Atele, Tongatapu, } \\
\text { Tonga }\end{array}$ & 13.5 & 1.4 & 6.3 & 54.0 & 13.7 & 17.3 & $\begin{array}{l}\text { Stantis 2015; Stantis et } \\
\text { al. } 2016\end{array}$ \\
\hline $\begin{array}{l}\text { Ha'ateiho, } \\
\text { Tongatapu, Tonga }\end{array}$ & 7.5 & 2.7 & 7.5 & 11.8 & 28.5 & & $\begin{array}{l}\text { Pietrusewsky et al. } \\
2019\end{array}$ \\
\hline Hawaiian Islands & 9.8 & - & - & - & - & - & Keene 1986 \\
\hline $\begin{array}{l}\text { Honokahua, Maui, } \\
\text { Hawai'i }\end{array}$ & 13.5 & & 9.6 & 6.8 & 51.7 & - & $\begin{array}{l}\text { Pietrusewsky and } \\
\text { Douglas } 1994 \text { cited in } \\
\text { Pietrusewsky et al. } \\
2019\end{array}$ \\
\hline $\begin{array}{l}\text { Rapa Nui/Easter } \\
\text { Island }\end{array}$ & 27.1 & & - & - & - & - & Owsley et al. 1985 \\
\hline $\begin{array}{l}\text { Early Māori, New } \\
\text { Zealand }\end{array}$ & - & 18.0 & - & - & - & - & Kieser et al. 2001 \\
\hline $\begin{array}{l}\text { Early Maori and } \\
\text { Moriori }\end{array}$ & & - & 29.2 & - & - & - & Taylor 1962 \\
\hline $\begin{array}{l}\text { Wairau Bar, New } \\
\text { Zealand }\end{array}$ & 4.8 & 11.5 & 8.2 & - & - & - & Buckley et al. 2010 \\
\hline
\end{tabular}




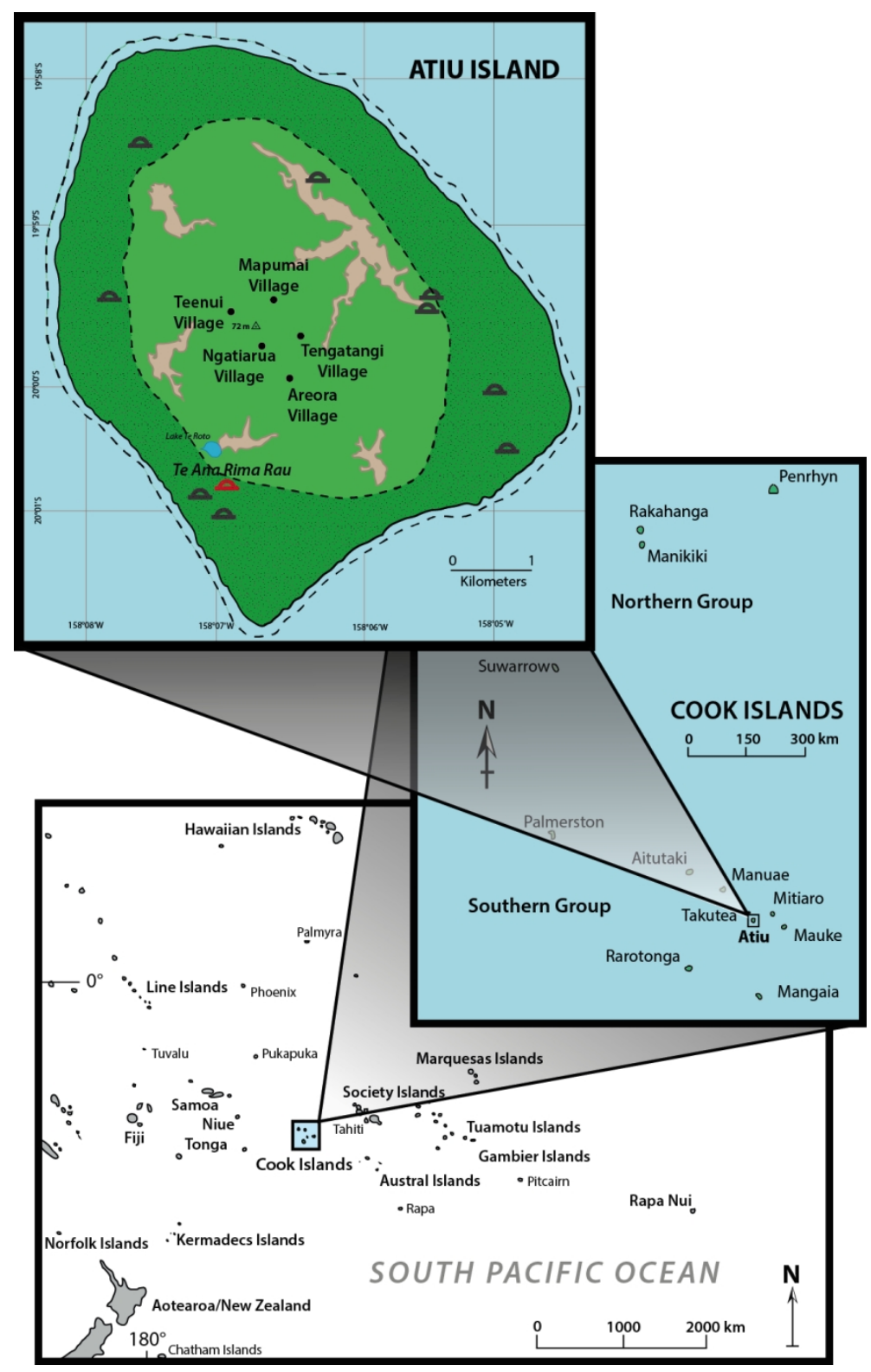

Figure 1. Map of the Pacific, Southern Cook Islands and Atiu showing the locations of islands and places mentioned in this paper. Locations of the caves on Atiu from Steadman (1991) and Trotter (1974). 


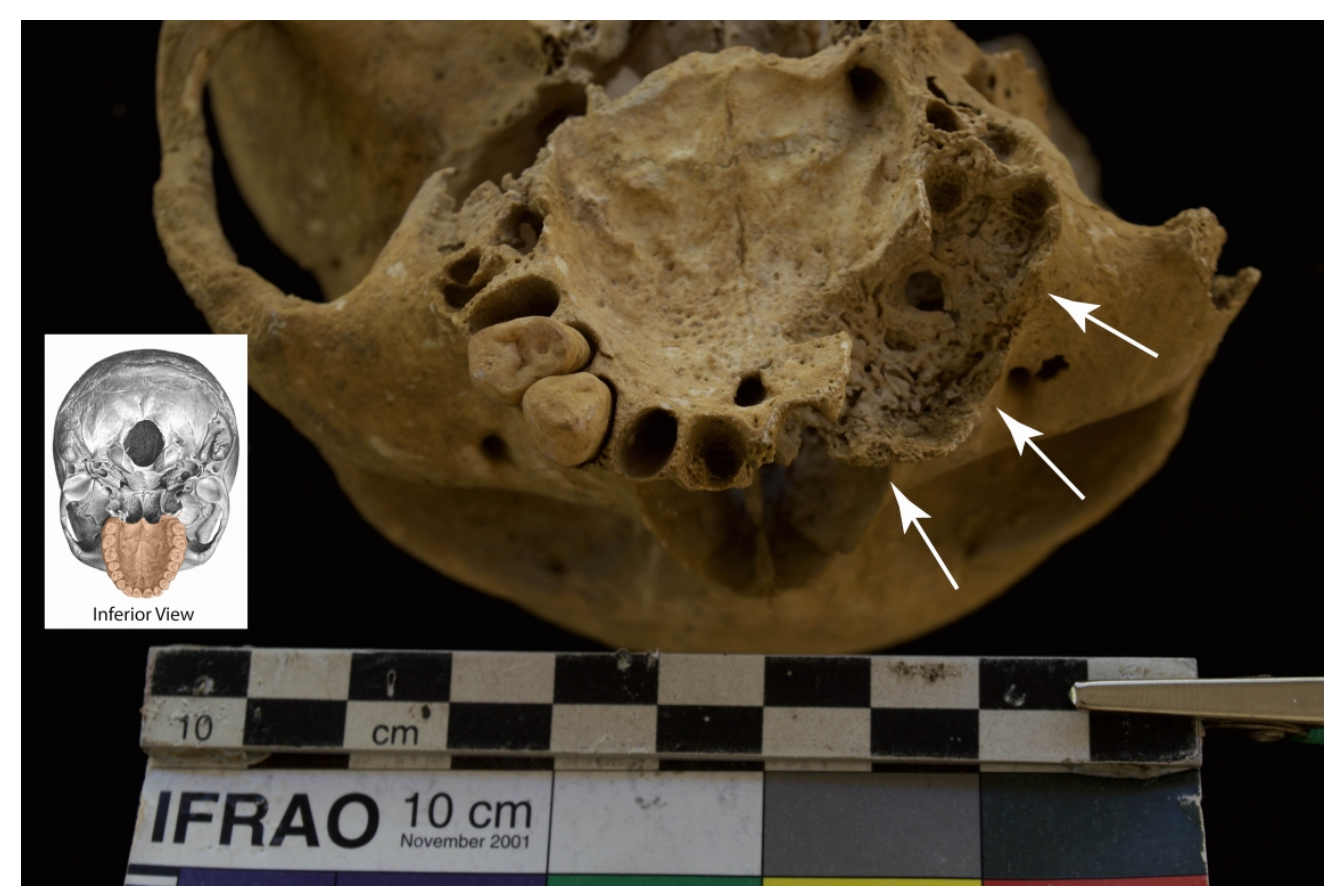

Figure 2a. Inferior view of maxilla. Periapical cavity in a young adult female. Pathological bone changes are consistent with a response to infection affecting the anterior right maxilla with lesions penetrating into the right maxillary sinus (indicated by white arrows).

$636 \times 423 \mathrm{~mm}$ ( $300 \times 300$ DPI) 


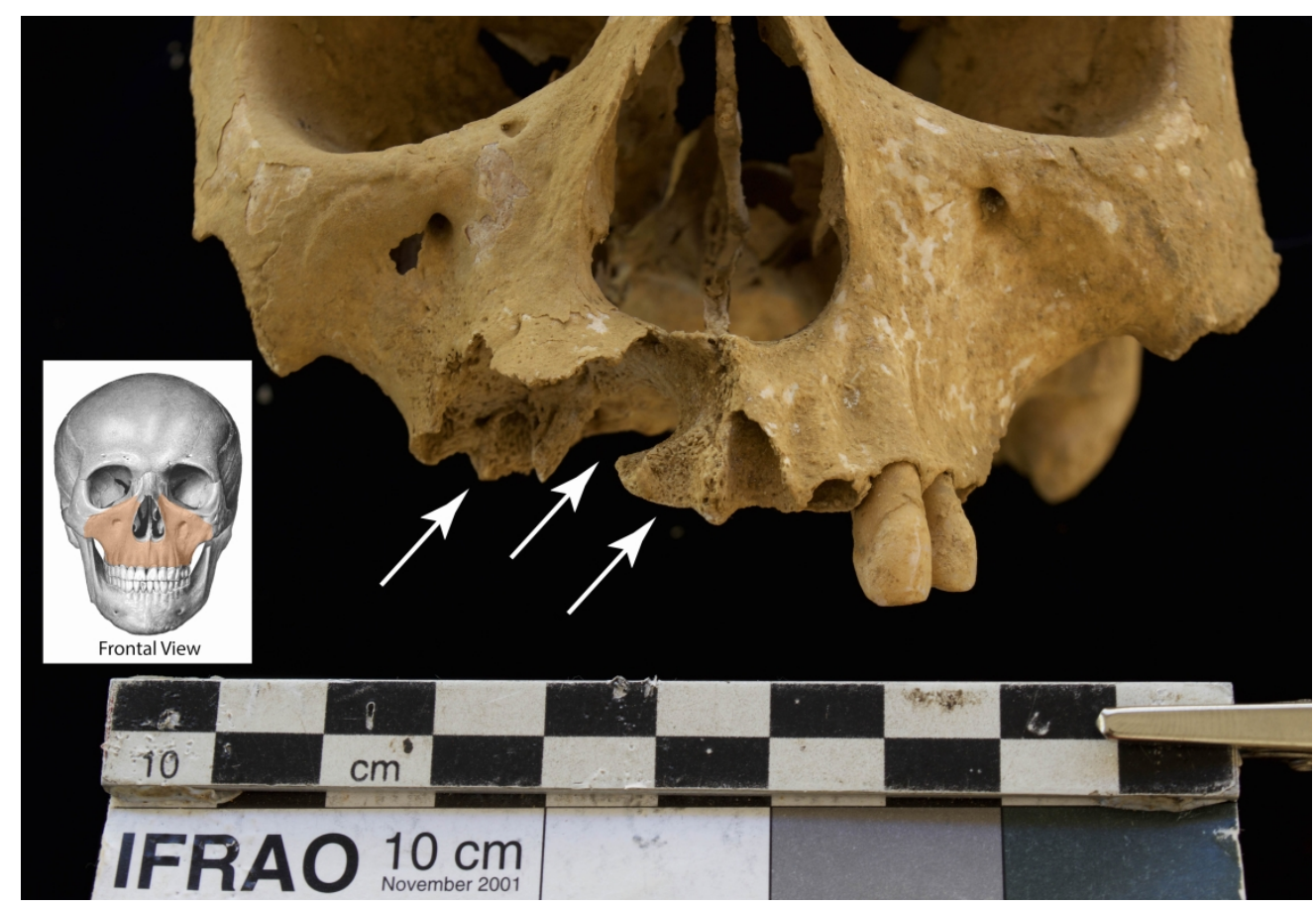

Figure 2b. Frontal view of maxilla. Periapical cavity in a young adult female. Pathological bone changes are consistent with a response to infection affecting the anterior right maxilla with lesions penetrating into the right maxillary sinus (indicated by white arrows).

$$
613 \times 420 \mathrm{~mm}(300 \times 300 \mathrm{DPI})
$$




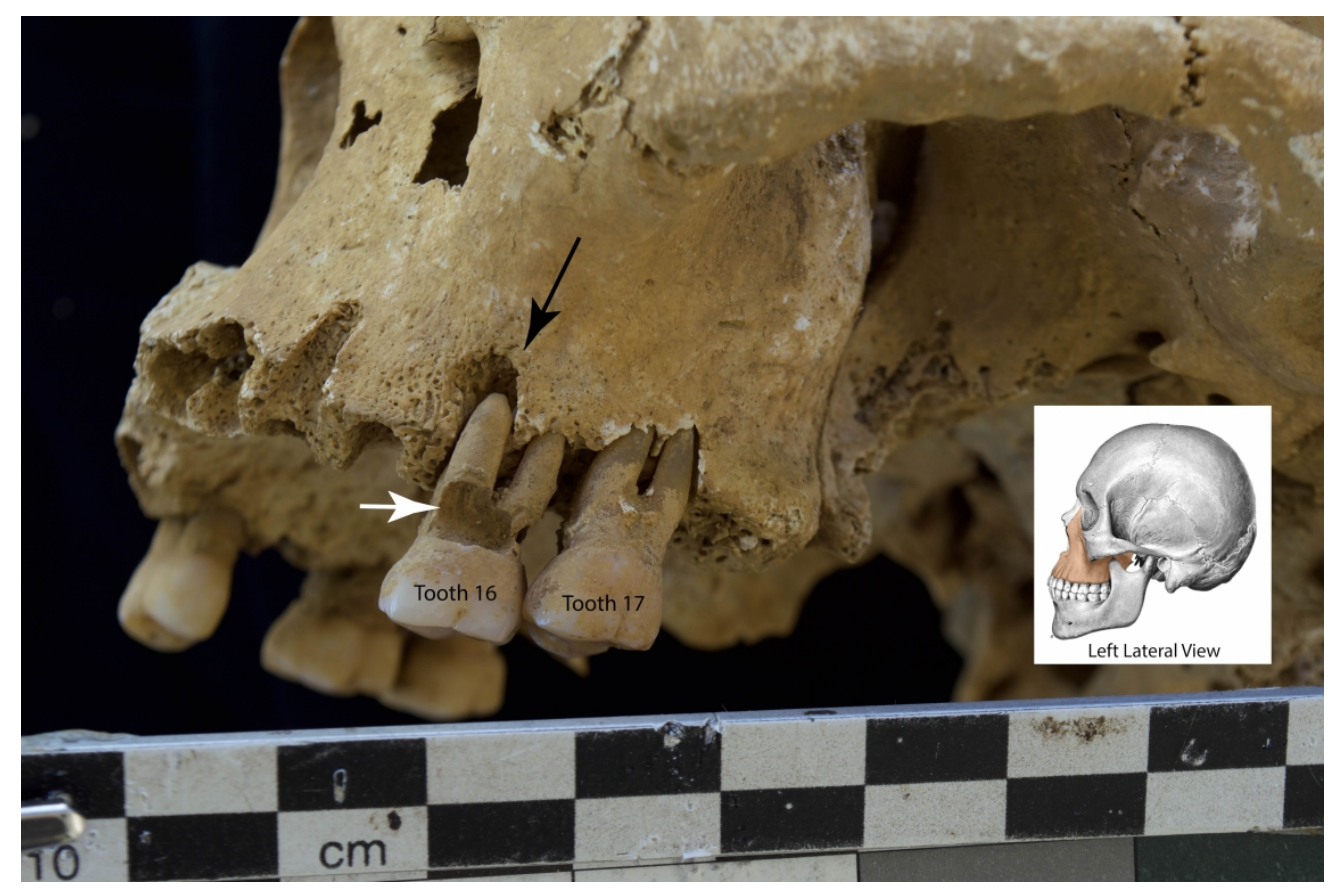

Figure 3. Lateral left view of cranium. Periapical cavity on upper left first permanent molar for a young adult female (indicated by black arrow). Oral pathology for tooth 16 and 17 also includes severe alveolar resorption, slight calculus, and a large buccal root caries on tooth 16 (indicated by white arrow). Antemortem tooth loss observed for tooth 18 .

$530 \times 352 \mathrm{~mm}(300 \times 300 \mathrm{DPI})$ 